\title{
$\begin{array}{llllllllllll}\mathbf{S} & \mathbf{P} & \mathbf{R} & \mathbf{A} & \mathbf{W} & \mathbf{O} & \mathrm{Z} & \mathbf{D} & \mathbf{A} & \mathbf{N} & \mathbf{I} & \mathbf{A}\end{array}$
}

Prawo Kanoniczne

58 (2015) nr 4

\section{Sprawozdanie z Międzynarodowej Konferencji Naukowej Stowarzyszenia Kanonistów Polskich poświęconej zadaniom nauczycielskim Kościoła wobec nowych wyzwań}

Na zaproszenie biskupa diecezji łomżyńskiej ks. dra Janusza Stepnowskiego kanoniści z Polski i zagranicy spotkali się na corocznej konferencji naukowej. Tym razem tematem obrad było zagadnienie zadania nauczycielskiego Kościoła wobec wyzwań jakie niesie ze sobą współczesny świat.

Obrady konferencji odbywały się w Zespole Szkół Katolickich w Łomży w dniach 8-9 września 2015 roku. W przygotowanie spotkania polskich kanonistów zaangażowane były różne instytucje: Stowarzyszenie Kanonistów Polskich, Kuria Diecezjalna i Sąd Biskupi w Łomży, Wydział Nauk Prawnych Towarzystwa Naukowego KUL, a także Katedra Kościelnego Prawa Publicznego i Konstytucyjnego KUL i łomżyńskie Seminarium Duchowne.

Obrady rozpoczęly się od powitania uczestników i prelegentów przez Prezesa Stowarzyszenia Kanonistów Polskich ks. prof. dra hab. Józefa Krukowskiego. Zaliczany do grona najwybitniejszych polskich kanonistów ks. J. Krukowski podkreślił, że Kościół głosi Prawdę, która jest dzisiaj zagrożona przez coraz silniejsze wpływy wrogich ideologii, stąd rosnące zainteresowanie prawników kościelnych misją nauczania Kościoła. Konferencja, jak zaznaczył Prezes SKP, jest odpowiedzią na potrzeby czasu. Po przedstawieniu harmonogramu obrad ks. J. Krukowski stwierdził, że Łomża stała się przez dni obrad kanonistów stolicą nauki prawa kanonicznego w Polsce. Głos zabrali także gospodarze spotkania: ks. prał. dr Ireneusz Borowski, oficjał łomżyńskiego sądu oraz ks. bp dr Janusz Stepnowski, który został włączony w poczet honorowych członków Stowarzyszenia Kanonistów Polskich. Następnie członek zarządu Stowarzyszenia ks. prof. dr hab. Mirosław Sitarz odczytał pozdrowienia i listy od biskupów polskich skierowane na ręce Księdza Prezesa. Listy przysłali: ks. Zenon kard. Grocholewski, były prefekt Kongregacji Wychowania Katolickiego, ks. Henryk kard. Gulbinowicz, Arcybiskup Senior Archidiecezji Wrocławskiej, bp Artur Miziński, Sekretarz Generalny Konferencji Episkopatu Polski, bp Tadeusz Pikus, 
ordynariusz diecezji drohiczyńskiej, bp Andrzej Dziuba, biskup diecezjalny łowicki, biskup sandomierski Krzysztof Nitkiewicz, biskup polowy Wojska Polskiego Józef Guzdek oraz inni przedstawiciele władz kościelnych.

Harmonogram konferencji uległ niewielkim zmianom w związku z nieobecnością ks. prof. dra hab. Vytautasa Steponasa Vaičiūnasa z Uniwersytetu Witolda Wielkiego w Kownie oraz ks. prof. dra hab. Tadeusza Guza z Katolickiego Uniwersytetu Lubelskiego Jana Pawła II.

Obradom pierwszej sesji łomżyńskiej konferencji przewodnicznył biskup pomocniczy tej diecezji ks. Tadeusz Bronakowski. Ksiądz biskup przedstawił prelegentów i składając najlepsze życzenia urodzinowe ks. Januszowi Mariańskiemu poprosił go o zabranie głosu. Wystąpienie ks. J. Mariańskiego z Katolickiego Uniwersytetu Lubelskiego dotyczyło socjologicznej analizy światowego społeczeństwa i wyłożenia zarysu zagrożeń z jakim radzić sobie musi zarówno współczesny człowiek, jak i Kościół. Kreśląc sytuację socjologiczną świata, prelegent wyróżnił współczesne megatrędy, do których zaliczył: pluralizm wartości norm, społeczeństwo ryzyka, społeczeństwo egoistów, społeczeństwo zdezorientowane, społeczeństwo bez wartości i norm. Przedstawiając zagrożenia ks. J. Mariański stwierdził, że działalność Kościoła powinna polegać na pastoralnej trosce, dialogu i faktycznym przestrzeganiu norm i wartości deklaratywnie przyjętych przez Magisterium. Ponadto zauważył, że pod żadnym pozorem hierarchia nie może pozwolić na dostosowywanie się Owczarni Chrystusa do współczesnego świata, bo stanie się niczym innym jak przedsiębiorstwem usług. Tak samo nie można dopuścić do hermetyczności Kościoła, bowiem taka postawa zrodzić może Kościół mniejszości, a nawet sektę. Skonstatował, że najlepszym rozwiązaniem i odpowiedzią Kościoła na wspólne wyzwania jest cierpliwe i miłosierne zatroskanie o każdego człowieka takim jakim on jest.

Kolejnym prelegentem był ks. prof. dr hab. Józef Krukowski, jeden z gospodarzy konferencji. Wygłosił wykład pod tytułem Natura i przedmiot misji nauczycielskiej Kościoła. Prezes SKP zarysowując ten obszerny temat zauważył, że natury Kościoła nie można zrozumieć jedynie przez naturalny rozum, należy w poszukiwaniach prawdy sięgać do Objawienia Bożego, czyli łaski wiary. Zasadniczą misją Kościoła jest nauczanie Prawdy Objawionej, czyli uniwersalnej i zarazem obiektywnej. Jak stwierdził ks. J. Krukowski poszukiwanie i nauczanie Prawdy jest zatem własnym prawem i jednocześnie obowiązkiem całej wspólnoty Kościoła, szczególnie zaś tych którym to zadanie powierzył Chrystus Pan poprzez sakrament święceń. 
Po pierwszej sesji rozpoczęła się żywa dyskusja, którą prowadził przewodniczący ks. bp T. Bronakowski. Pani Jolanta Łodzińska, pracownik Instytutu Socjologii, skierowała swoje pytanie do pierwszego z prelegentów. W swojej wypowiedzi podkreśliła, że zabrakło jej w wystąpieniu ks. J. Mariańskiego pełniejszego obrazu społecznych zagrożeń poprzez metaforyczne stwierdzenie smog jest demokratyczny a bieda hierarchiczna. Wspomniała o zagrożeniach publicznie znanych, takich jak zapłodnienie metodą in vitro, niebezpieczne eksperymenty medyczne, wpływ ideologii wrogich naturze ludzkiej na współczesne systemy polityczne i prawne. Zaznaczyła, że współczesny człowiek jako jednostka pozostawiony jest sam sobie, a przywołując Jana Pawła II stwierdziła, że jego słowa stały się prorocze. Świat już nie staje się, ale jest „cywilizacją śmierci”. W odpowiedzi na postawione przez J. Łodzińską kwestie ks. J. Mariański zauważył, że socjologia zna wiele megatrędów, a on w swoim wystąpieniu wyliczył tylko te, które uważał za najistotniejsze, ze względu na to, że nie wszystkie jest w stanie omówić. Sekularyzacja i desekularyzacja są głównym przedmiotem badań prelegenta. Ksiądz Profesor przytoczył wyniki badań socjologów przeprowadzonych na grupie warszawskich licealistów, świadczą one o tym, że wśród badanych istnieją mocne procesy indywidualizacji, a jednocześnie jest w nich ogromna potrzeba wspólnoty. Kończąc socjolog zauważył, że kanoniści są budowniczymi mostów: między Chrystusem a człowiekiem, Kościołem a państwem, Ewangelią a działaniem osoby i życzył wszystkim prawnikom kościelnym wytrwałości w realizacji tych zadań.

Głos w dyskusji zabrał także ks. prof. dr hab. Józef Krzywda z Uniwersytetu Papieskiego Jana Pawła II w Krakowie. Zapytał, w związku z referatem ks. Krukowskiego, o to jak postępować z wiernymi. Jakimi metodami dotrzeć z Prawdą, którą trudno odnaleźć we współczesnym świecie, szczególnie w mediach? Ks. J. Krukowski odpowiadając na pytanie zaznaczył, że między Kościołem instytucjonalnym a wiernymi stoi granica stworzona przez sekularyzowane media. Rozwiązaniem takiej sytuacji jest jedynie budowanie środków przekazu alternatywnych dla świeckich mediów.

W dyskusji wypowiedział się także bp Marian Buczek, który krótko stwierdził, że pseudokatolicy bałamucą wiernych, a biskupi bardzo często udają, że nie widzą problemu i milczą.

Po przerwie kawowej rozpoczęła się druga sesja Konferencji, której przewodniczył ks. prof. dr hab. Piotr Stanisz, dziekan Wydziału Prawa, Prawa Kanonicznego i Administracji Katolickiego Uniwersytetu Lubelskiego. 
Pierwszy referat drugiej sesji wygłosił ks. bp Antoni Dziemianko, biskup diecezjalny piński, który mówił o działalności Konferencji Biskupów Białorusi wobec nowych wyzwań. Biskup A. Dziemianko opisał sytuację społeczno-religijną na Białorusi zaznaczając, że specyficznie białoruskim wyzwaniem dla Kościoła są katastrofy ekologiczne i technogenne oraz powszechny alkoholizm. Hierarchia radzi sobie z tymi problemami poprzez rozwój szkół katolickich i choć w tym momencie nie ma na Białorusi katolickiego uniwersytetu to pojawiły się prośby władz państwowych o jego erekcję. Odpowiedzią kapłanów i biskupów na problemy współczesnego społeczeństwa białoruskiego są homilie, grupy Anonimowych Alkoholików, prace odpowiedniego zespołu Episkopatu, media katolickie i poruszanie ruchów wspólnotowych. Ponadto, mimo bardzo małej liczby powołań i ciągłego braku kapłanów, erygowane są kaplice, których głównym celem jest ściągniecie młodych ludzi, którzy nie znajdują się w biedzie ekonomicznej, ale coraz głośniej wołają o Boga.

Kolejnym prelegentem był emerytowany biskup ukraińskiej diecezji charkowsko-zaporoskiej bp Marian Buczek. Tematem jego referatu była postawa Konferencji Biskupów Ukrainy wobec wyzwań jakie niesie za sobą współczesność. Na Ukrainie mieszka około miliona katolików, którzy zgromadzeni są wokół siedmiu diecezji. Istotna w odpowiedzi na wyzwania współczesności jest współpraca biskupów łacińskich z biskupami katolickich obrządków wschodnich. Działalność Kościoła ukraińskiego skupiona jest wokół zwyczajnego nauczania biskupów poprzez homilie, listy pasterskie a także wykorzystywane są środki masowego przekazu. Interesujące jest to, że mimo działalności laickich mediów w lansowaniu tak zwanych małżeństw homoseksualnych nie przyjmuje się ten trend w tradycyjnym ukraińskim środowisku. Biskup M. Buczek stwierdził, że dużym problemem jest brak przygotowania do sakramentów świętych we wspólnotach prawosławnych, obowiązkowi temu zadość czynią kapłani katoliccy. Nadrabiane są także zaległości w związku z nauczaniem religii w szkołach, lekcje te były zakazane w czasach ateizmu wojującego z Kościołem katolickim.

Po wystąpieniach biskupów pracujących za wschodnią granicą Polski rozpoczęła się dyskusja, w której głos zabrał ks. prof. dr hab. Józef Wroceński, wieloletni Dziekan Wydziału Prawa Kanonicznego Uniwersytetu Kardynała Stefana Wyszyńskiego w Warszawie. Ksiądz J. Wroceński zapytał ks. bpa A. Dziemiankę o kroki związane z zawarciem konkordatu między Stolicą Apostolską a Rządem Białorusi. Jak wygląda dzisiaj postęp tych prac. W odpowiedzi na postawione pytanie biskup piński stwierdził, że 
zdecydowanie zmniejszyło się nasilenie rozmów. Zasadniczą przeszkodą do podpisania umowy konkordatowej jest fakt, że władze państwowe wolałyby zawrzeć porozumienie z Kościołem partykularnym, co jest sprzeczne z przepisami prawa kanonicznego. Prelegent podkreślił, że pragnienie podpisania konkordatu jest nadal żywe, ale jednocześnie zaznaczył, że nie wszystko zależy od Konferencji Episkopatu Białorusi i Stolicy Apostolskiej.

Uzupełnieniem wystąpień księży biskupów był referat ks. bpa dra Stanisława Stefanka, byłego ordynariusza diecezji łomżyńskiej pod tytułem Konferencja Episkopatu Polski wobec nowych wyzwań. Biskup S. Stefanek skupił się głównie na trosce Kościoła o rodzinę, co było niewątpliwie istotne zwłaszcza ze względu na zbliżający się Synod Biskupów poświęcony tej tematyce. Wyraził głębokie ubolewanie ze względu na niedocenianie, także przez katolickich naukowców, nauk o rodzinie jako dyscyplinie ściśle naukowej. Stwierdził, że takie podejście związane jest z podporządkowaniem nauk humanistycznych reżimowi technicznemu. Problemy współczesnego świata, zdaniem ks. bpa S. Stefanka, wynikają ze zmiany mentalności ludzi i braku wiary. Antidotum na pojawiające się trudności zastosowanym przez Konferencję Episkopatu Polski jest Nowa Ewangelizacja, którą można streścić w trzech zasadniczych słowach kluczach: słuchanie, myślenie, działanie. Kończąc prelegent zaznaczył, że szczególnie w nauczaniu potrzeba jest nowa metoda i logika, głównie w szkołach które otrzymują miano katolickich. Ksiądz Biskup zakończył swoje przemówienie metaforycznym stwierdzeniem, że salki parafialne nie powinny zostać zamieniane na domy pogrzebowe, ale powinny nieustannie tętnić życiem.

Po wystąpieniu biskupa seniora diecezji łomżyńskiej kontynuowano dyskusję, w której głos zabrał ks. prof. dr hab. Ryszard Sztychmiler, Kierownik Katedry Prawa Kanonicznego i Wyznaniowego Wydziału Prawa i Administracji Uniwersytetu Warmińsko-Mazurskiego w Olsztynie. Poprosił o wyjaśnienie sytuacji Instytutu Studiów nad Rodziną w Łomiankach. Ks. bp S. Stefanek zauważył, że Instytut Studiów nad Rodziną Uniwersytetu Kardynała Stefana Wyszyńskiego stał się wydziałem i pozornie jest idealnie. Problem w tym, że po czterdziestu latach działalności, jak stwierdził prelegent, zamknięto ośrodek w Łomiankach, a było w nim coś więcej niż akademickie korytarze i aule wykładowe. Chodzi o zlikwidowanie pewnego ruchu, który znaczył więcej niż państwowe rozporządzenia. Prelegent uzupełnił jeszcze swoje wystąpienie obrazując problemy współczesnego świata jako leasing obowiązków duszpasterskich przez biskupów i kapłanów. Zaznaczył, że konieczne jest trwałe i ciągłe podejmowanie obowiązków 
stanu przez wszystkich chrześcijan. Nie możemy dopuścić, jak zaznaczył bp S. Stefanek, aby zewnętrze przerzucanie obowiązków uśpiło władze kościelne, szczególnie w zakresie przygotowania do przyjęcia sakramentu małżeństwa.

Kończąc dyskusję przewodniczący drugiej sesji ks. P. Stanisz zaprosił wszystkich zebranych na uroczystość odnowienia doktoratów ks. prof. dr. hab. Wojciecha Góralskiego i o. dr. Gabriela Bartoszewskiego 21 października 2015 roku w Lublinie.

Trzeciej sesji przewodniczył ks. prof. dr hab. Andrzej Pastwa, Kierownik Katedry Prawa Kanonicznego i Ekumenizmu Uniwersytetu Śląskiego w Katowicach.

Konferencja Biskupów Hiszpanii wobec nowych wyzwań to temat, który referował ks. prof. dr hab. Piotr Ryguła. Podkreślił, że ze względu na ograniczony czas wystąpienia skupi się jedynie na wstępie i zakończeniu. Ponadto zaprosił uczestników konferencji zainteresowanych tematem do sięgnięcia po publikację, która ukaże się w najbliższym czasie. W wystąpieniu ks. P. Ryguła zauważył, że historia Hiszpanii przesiąknięta jest wpływem wiary, niemniej współcześnie pojawiające się problemy dotyczą także tego, jak się okazuje pozornie katolickiego kraju. Zaznaczył, że religia jest zasadniczym i ważnym elementem państwowości hiszpańskiej. Wojna domowa z 1936 roku ukazała istniejący podział społeczeństwa podparty nieobiektywnymi opiniami kreowanymi zarówno przez państwo, jak i Kościół. Prelegent podkreślił, że sekularyzacja Hiszpanii dokonała się pod wpływem czynników zewnętrznych, wynikających głównie z antyklerykalizmu. Następnym elementem tego procesu była obojętność społeczeństwa na treść nauczania Kościoła i w konsekwencji odchodzenie od praktyk religijnych. Ks. P. Ryguła zaznaczył, że kryzys hiszpański widziany jest wyraźnie w statystykach dotyczących wyświęcanych kapłanów. W 1965 roku było ich 800, gdy w parę lat później musiano zamykać seminaria. Ostatnim etapem procesu sekularyzacji, na który zwrócił uwagę prelegent, jest całkowite odejście od wiary w Boga na rzecz ateizacji i agnostycyzmu. Ksiądz Profesor z przykrością stwierdził, że ta sytuacja jest już głęboko zakorzeniona w społeczeństwie hiszpańskim.

Kolejnym prelegentem trzeciej sesji Konferencji był o. Damián Nĕmec, dominikanin z Uniwersytetu w Ołomuńcu, który wygłosił referat pod tytułem Konferencja Biskupów Czech wobec nowych wyzwań. Prelegent po wprowadzeniu historycznym zaznaczył, że Konferencja Biskupów Czech jest stosunkowo młodą instytucją, bo powstałą jako gremium autonomiczne 
dopiero po podziale Czechosłowacji w 1993 roku. Działalność czeskich biskupów skupia się na listach pasterskich (przygotowanie do Millenium, wizyty Ojca Świętego, problemy społeczne) i listach do społeczności cywilnej, co stanowi niewątpliwe novum. Ponadto, Konferencja Biskupów Czech odpowiadając na problemy współczesnego świata zainicjowała powstanie Narodowego Centrum do spraw Rodziny. Istnieje także wiele centrów diecezjalnych, a w niektórych diecezjach także dekanalnych instytucji wspierających rodzinę. Problemem z jakim borykają się czescy biskupi jak zaznaczył prelegent jest katechizacja. Od 1953 roku nauka religii w szkole jest fakultatywna, martwią jednak dane. Tylko 10 procent uczniów w szkołach podstawowych i 0,5 procenta uczniów szkół średnich zdeklarowało chęć uczęszczania na lekcje religii. Ojciec D. Nĕmec stwierdził, że trwają prace nad nowym modelem katechizacji, który ma na celu skupienie katechezy $\mathrm{w}$ parafiach, $\mathrm{z}$ zaznaczeniem, że nauka religii w szkole pozostanie fakultatywna.

Ostatnim wystąpieniem w pierwszym dniu Konferencji Stowarzyszenia Kanonistów Polskich był referat ks. dr hab. Józefa Marčina z Katolickiego Uniwersytetu w Ružomberku, który w punktach przedstawił sytuację Konferencji Episkopatu Słowacji wobec nowych wyzwań. Odpowiedzią na wymagania nauczania i katechizacji jest na Słowacji powstałe 14 marca 2005 roku Centrum Pedagogiczne i Katechetyczne. Ponadto Uniwersytet w Ružomberku ma ściśle katolicki charakter i realizuje posługę nauczania poprzez wydziały: teologiczny, nauk o zdrowiu i filozoficzny. Drugi punkt wystąpienia ks. J. Marčina dotyczył listów pasterskich kierowanych przez Konferencję Episkopatu Słowacji do wiernych. Zajmowały się one współczesnymi problemami, a w szczególności zachęcały do podejmowania studiów w katolickich szkołach wyższych, dotykały problemu jogi w szkołach publicznych a także poruszały problemy współczesnej młodzieży. Trzeci punkt referatu gościa ze Słowacji dotyczył troski biskupów tego kraju o małżeństwa i rodziny, która skupia się głównie na ujednoliceniu zasad dotyczących udzielania dyspensy od formy kanonicznej, prawa do sprzeciwu sumienia wszystkich obywateli zagwarantowanego przez umowę ze Stolicą Apostolską i władzami państwowymi. Co więcej, prelegent zauważył, że istnieje typowo słowacka praktyka pisania listów opisujących sytuację osób rozwiedzionych lub trwających w separacji do biskupa diecezjalnego. Ludzie ci nie żyjąc w nowych związkach nie popełniają grzechu ciężkiego i nie są odłączeni od stołu eucharystycznego. Jak stwierdził mówca, praktyka ta ma na celu uspokojenie sumienia osób, które znajdują się w tej niekomfortowej 
i trudnej sytuacji życiowej. Ksiądz J. Marčin na koniec wystąpienia postawił retoryczne pytania skierowane do uczestników konferencji, w większości kapłanów: Czy środki, które podejmujemy sa wystarczające? Co należy jeszcze zrobić, aby zatrzymać i utrzymać wiarę w coraz bardziej sekularyzowanej Europie?

Nastąpiła żywa dyskusja, którą rozpoczął poruszony wystąpieniem ks. P. Ryguły, ks. J. Krukowski, który zapytał prelegenta czy w Hiszpanii istnieje jeszcze Konferencja Biskupów. Prezes Stowarzyszenia Kanonistów Polskich stwierdził, że słyszał historię jakoby hiszpańskie siostry zakonne jeździły do czeskiej Pragi, aby tam uczyć się od marksistów sekularyzacji społeczeństwa. Odpowiadając ks. P. Ryguła usprawiedliwił się, stwierdzając, że przedstawił tylko wstęp przygotowanego przez siebie referatu, stąd można było błędnie wywnioskować, że w Hiszpanii nie ma lub działa nieprawidłowo Konferencja Biskupów. Kluczem jaki wybrał prelegent do przedstawienia poruszonej problematyki było ukazanie specyfiki Hiszpanii i działającego tam Kościoła. Hiszpania, jak stwierdził prelegent, żyje swoimi własnymi problemami, czyli głównie kwestami politycznymi.

Głos w dyskusji zabrał także ks. J. Krzywda, który przedstawił swoje zarzuty wobec wystąpienia ks. P. Ryguły. Zdaniem ks. J. Krzywdy zabrakło $\mathrm{w}$ wystąpieniu prelegenta rzeczywistych problemów Hiszpanów oraz przedstawienia prób ich rozwiązania, które podejmuje Konferencja Biskupów w tym kraju. Zauważył, że żadna z Konferencji Episkopatów nie korzysta w swojej działalności z ogromnego autorytetu jaki przysługuje biskupom. W związku z taką postawą następców Apostołów ich rolę zaczynają spełniać osoby, które mają własne pomysły i wizje nauczania Kościoła.

Uzupełnieniem stanowiska ks. prof. J. Krzywdy była wypowiedź ks. prof. dr. hab. Wiesława Wenza, Kierownika Katedry Prawa Kanonicznego i Prawa Wyznaniowego Papieskiego Wydziału Teologicznego we Wrocławiu. Przytaczając wypowiedź hiszpańskich biskupów w kontekście rodziny i małżeństwa, zauważył, że odpowiedzią Episkopatu Hiszpanii na współczesne problemy jest wspólny list z Konferencją Episkopatu Włoch zawierający instrukcję zarówno dla wiernych, jak i duchownych, dotyczącą zawierania małżeństw katolików z muzułmanami, którzy jako uchodźcy przybywają często i licznie do obu tych państw.

Swój udział w dyskusji miał także ks. mgr lic. Henryk Kleps, Obrońca Węzła Małżeńskiego w Sądzie Metropolitalnym Warszawskim. Ks. H. Kleps zapytał na ile uwzględniono postanowienia Soboru Watykańskiego II. Poddał w wątpliwość otwarcie się Kościoła na wiernych, które nastąpiło po 
zakończeniu obrad ostatniego soboru powszechnego. Stwierdził, że mimo górnolotnych założeń laicyzacja społeczeństwa dalej postępuje.

W odpowiedzi na pytanie ks. H. Klepsa, prelegent ks. P. Ryguła stwierdził, że w sytuacji hiszpańskiej ciężko jest zaaplikować normy soborowe szczególnie znoszące państwa wyznaniowe, ponieważ podział instytucjonalny zawsze był albo wrogi, na wzór Francji, albo była ścisła współpraca. W okresie działalności politycznej generała Franco, jak zaznaczył wykładowca UKSW, powstała ustawa o wolności religijnej, ale dopiero po Soborze Watykańskim II wprowadzono neutralność państwa i Kościoła.

Pan doktor Michał Zawiślak z Katolickiego Uniwersytetu Lubelskiego poprosił ks. prof. Piotra Rygułę o przedstawienie przykładów sekularyzacji. W odpowiedzi ks. P. Ryguła stwierdził wyraźnie, że społeczeństwo hiszpańskie na tyle daleko odeszło od tematów i problemów moralnych Kościoła, że można powiedzieć, iż problematyka ta już ich nie dotyczy. W Polsce te tematy są jeszcze gorące i poruszają opinię publiczną, są ważne, inaczej jest na półwyspie Iberyjskim.

Po zakończeniu dyskusji przez ks. prof. dra hab. Andrzeja Pastwę odbyło się Walne Zebranie Stowarzyszenia Kanonistów Polskich podczas którego został wybrany nowy zarząd tej organizacji. Na czele Stowarzyszenia stanął ponownie ks. prof. dr hab. Józef Krukowski, który wybrany został przez aklamację. Walne Zebranie Stowarzyszenia Kanonistów Polskich wieńczyło pierwszy dzień obrad tego gremium w Łomży.

Drugi dzień konferencji otworzył ks. prof. dr hab. Ryszard Sztychmiler, który na wstępie zaprosił do stołu prezydialnego ks. prof. dra hab. Wojciecha Góralskiego, ks. prof. dra hab. Zbigniewa Janczewskiego oraz ks. prof. dra hab. Jana Krajczyńskiego.

Ze względu na opublikowane dzień wcześniej motu proprio papieża Franciszka Mitis Iudex Dominus Jesus ks. W. Góralski postanowił zmienić temat swojego wystąpienia i omówić, ze względu na prośby uczestników konferencji dokument reorganizujący w znacznym stopniu kanoniczny proces o stwierdzenie nieważności małżeństwa. W związku z powyższym prof. W. Góralski wygłosił jedynie wstęp i zakończenie swojego referatu dotyczącego Zadań uniwersytetów kościelnych i katolickich wobec nowych wyzwań. Znakomity prelegent zarysował w kilku zdaniach obrany przez siebie temat. Konkluzją jest to, że uniwersytety katolickie powinny świecić nie ilością studentów, lecz umiłowaniem nauki. Ponadto, powinny zdaniem ks. W Góralskiego, tworzyć jedność wiedzy w pełnym wymiarze, kształtować i przezwyciężać różnice między kulturą i wiarą. Prelegent wskazał 
także wyzwania jakie stoją przed katolickimi i kościelnymi uniwersytetami: otwarcie na mądrość niech będzie odpowiedzią na relatywizm, przestrzeganie norm prawnych niech będzie światłem dla innych, a nadto, konieczne jest wiernie zachowanie tożsamości katolickiej.

Następnie ks. prof. W. Góralski przeszedł do omówienia podpisanego 15 sierpnia 2015 roku a opublikowanego 7 września tego samego roku dokumentu papieskiego Mitis Iudex Dominus Jesus. Normy zawarte w tym motu proprio wejdą w życie 8 grudnia 2015 roku. Już na wstępie ten jeden z najwybitniejszych kanonistów w zakresie prawa małżeńskiego zauważył, że ważne daty związane z tym dokumentem są świętami maryjnymi, i tak odpowiednio: Wniebowzięcie Najświętszej Maryi Panny, Narodzenie Najświętszej Marii Panny i Niepokalane Poczęcie Najświętszej Marii Panny.

Dokument zawiera doktrynalny wstęp, w którym Ojciec Święty Franciszek przedstawia podstawowe założenia reformy kościelnego procesu małżeńskiego i stanowczo podkreśla nierozerwalność małżeństwa. Papież zaznacza także, że jego podstawową troską jest zbawienie dusz, także tych osób, które żyją w związkach niesakramentalnych. Ks. W. Góralski wymieniając cele wydania omawianego dokumentu jako podstawowy podał przyspieszenie procesu, aby ci który maja watpliwość co do nieważności matżeństwa nie oczekiwali w ciemnościach czasu. Zasadnicze zmiany, które przynosi motu proprio to: jeden jedyny wyrok, jeden jedyny sędzia duchowny, sam biskup diecezjalny jest sędzią (de processus brevior) tj. nowa forma procesu o stwierdzenie nieważności małżeństwa oraz zadanie własne Konferencji Episkopatu w sprawie przyspieszenia procesów. Prelegent stwierdził także, że zmiany dotyczą składu kolegium sędziowskiego. Nowe normy zakładają, że przewodniczącym kolegium ma być osoba duchowna, zaś skład sędziowski mogą tworzyć osoby świeckie, i co istotne, nie muszą być to osoby po studiach w zakresie prawa kanonicznego. Normy regulują, aby były to osoby biegłe $\mathrm{w}$ teologii lub humaniści zaaprobowani przez biskupa diecezjalnego. Ponadto zmienia się właściwość trybunałów co do przyjęcia i prowadzenia procesu o stwierdzenie nieważności małżeństwa. Teraz będzie to, jak skonstatował ks. W. Góralski: miejsce zawarcia małżeństwa, (tu normy nie wprowadzają żadnych zmian), miejsce, gdzie jedna ze stron będzie miała zamieszkanie stałe lub tymczasowe oraz trybunał dowodowy ale bez konieczności uzyskania zgody oficjała sądu pierwszej właściwości.

Referat ks. prof. dra hab. Wojciecha Góralskiego opatrznościowo wpisał się w obrady łomżyńskiej konferencji. Niewątpliwie zmiany wprowadzone przez Stolicę Apostolską w procesie o stwierdzenie nieważności małżeństwa 
stawiają nowe wyzwania zarówno przed indywidualnymi biskupami diecezjalnymi, jak i zebranymi w kolegium Konferencji Episkopatu danej prowincji kościelnej.

Kolejnym prelegentem w przedostatniej sesji Konferencji Stowarzyszenia Kanonistów Polskich był ks. prof. dr hab. Zbigniew Janczewski, Kierownik Katedry Prawa o Posłudze Uświęcania Wydziału Prawa Kanonicznego Uniwersytetu Kardynała Stefana Wyszyńskiego w Warszawie. Tematem jego wystąpienia była Realizacja posługi nauczania podczas przygotowań do przyjęcia sakramentów wtajemniczenia chrześcijańskiego i uzdrowienia. Ks. Z. Janczewski na wstępie skupił się na realizacji posługi nauczania wobec katechumenów, rodziców i rodziców chrzestnych. Zaznaczył, że przygotowania do sakramentu chrztu świętego spoczywa głównie na dorosłych poprzez odpowiednie spotkania i permanentną formację każdego wiernego. Przedstawił także postulat, aby Konferencja Episkopatu Polski ustanowiła normy i program spotkań katechetycznych dla rodziców, którzy ze względu na brak wiary lub jej niepraktykowanie odłożyli chrzest dziecka. W takiej sytuacji lub gdy proboszcz po rozeznaniu takiej sytuacji odłoży chrzest, proponuje aby odczekać minimum miesiąc $\mathrm{w}$ trakcie którego rodzice ci będą odbywali specjalne katechezy. Uczestnictwo w takich spotkaniach należałoby traktować jako znak, urzeczywistnienie pragnienia, aby dziecko przyjęło chrzest w Kościele katolickim. Ponadto, jak zauważył prelegent, spotkania takie mogą pobudzić słabą wiarę lub zachęcić do jej praktykowania. Analizując sakrament namaszczenia chorych ks. prof. Z. Janczewski zauważył problem związany z grupowym udzielaniem tego sakramentu. Brakuje wiedzy wśród kapłanów, stąd ciężko wymagać jej od wiernych. Niemniej należy ich pouczać, kto może ten sakrament przyjmować. Ze względu na brak takiego pouczenia przyjmują go ci, którzy są do tego nieuprawnieni. Prelegent przytoczył normę kodeksową, która stwierdza wprost, że sakramentu namaszczenia chorych udziela się w sytuacji realnego niebezpieczeństwa śmierci lub starości. Profesor Z J Janczewski wysunął kolejny postulat, którym jest stała formacja wiernych i poszerzanie wiedzy duchownych.

Ostatnim wystąpieniem przewidzianym w tej sesji był wykład ks. prof. dra hab. Jana Krajczyńskiego, Kierownika Katedry Prawa o Posłudze Nauczania Wydziału Prawa Kanonicznego Uniwersytetu Kardynała Stefana Wyszyńskiego w Warszawie. Ks. prof. J. Krajczyński opracował zagadnienie Wykładu nauki chrześcijańskiej o małżeństwie z uwzględnieniem potrzeb czasu. $\mathrm{Na}$ wstępie prelegent próbował określić znaki czasu dotyczące małżeństwa, zaliczył do nich między innymi: przyznanie statusu małżeństwa związkom 
osób tej samej płci, deprawacja definicji małżeństwa jako związku kobiety i mężczyzny, problem płci kulturowej (portal Facebook przedstawia 56 typów płci), wzrost liczby rozwodów, absolutyzowanie wolności jednostki (egoizm), preferowanie wygodnego stylu życia i błędne przeświadczenie, że potomstwo niweczy karierę. Ks. J. Krajczyński stwierdził, że istnieje spisek przeciwko życiu, który będąc synonimem rozwoju prowadzi do powszechnego relatywizmu. Kanonista z Płocka wskazał czynniki służące rozwojowi małżeństwa: wzrost pasterskiej troski o każde małżeństwo, propagowanie personalistycznej wizji małżeństwa i jego sakramentalności. W kontraście prelegent przedstawił zagadnienia, które nie sprzyjają dobru małżeństwa: hedonizm, materializm, kultura indywidualistyczna, niewłaściwe rozumienie wolności i deprecjonowanie prawa Bożego. Wskazując na środki, które mogą posłużyć do wchłonięcia przez społeczeństwo katolickiej nauki o małżeństwie prelegent zauważył, że mają to być godziwe środki zmierzające do rozpowszechniania Prawdy, ponadto dużą wagę przykładać należy do wychowania w rodzinie, katechezy i przepowiadania Słowa Bożego.

Po wystąpieniach profesorów z Uniwersytetu Kardynała Stefana Wyszyńskiego w Warszawie podjęto dyskusję. Rozpoczął ją, uzupełniając wypowiedź ks. W. Góralskiego w sprawie nowego dokumentu papieskiego, ks. prof. dr. hab. Leszek Adamowicz z Katolickiego Uniwersytetu Lubelskiego. Stwierdził on, że świeżo wydane normy są niedokładne, choćby w tym co dotyczy braku reformy zwykłego procesu małżeńskiego, gdzie biskup diecezjalny potrzebuje zgody Konferencji Episkopatu w sprawie mianowania świeckiego do kolegium sędziowskiego. Ponadto wskazał na problem wynikający z rozumieniem apelacji do najstarszej sufraganii, trudno bowiem niekiedy określić która diecezja będzie w tym wypadku właściwa.

Ksiądz W. Góralski odpowiadając na wątpliwości ks. L. Adamowicza stwierdził, że motu proprio implicite uchyliło normy kodeksowe dotyczące procesu zwyczajnego. Ponadto podkreślił ogromną odpowiedzialność instruktora w procesie przed biskupem diecezjalnym, $w$ trzeciej, nowej formie procesu, którą nazwał roboczo procesem najkrótszym.

Pytanie zadał także ks. prof. dr hab. Arkadiusz Domaszk, adiunkt Wydziału Prawa Kanonicznego UKSW w Warszawie, stwierdzając, że współczesne uczelnie katolickie i kościelne powinny mieć jasno określoną tożsamość. Kierując pytanie do ks. W. Góralskiego, zauważył, że widoczny jest kryzys tożsamości uniwersytetu.

Przewodniczący tej sesji, ks. R. Sztychmiler także zabrał głos. Stwierdził, że istnieje duża potrzeba forum wykładowców prawa kanonicznego, 
aby dbać o kształcenie dobrych prawników. Zaproponował ks. Z. Janczewskiemu i ks. J. Krajczyńskiemu, aby przedstawili swoje wnioski de lege ferendae Konferencji Episkopatu Polski, która mogłaby promulgować potrzebne przepisy.

Ks. W. Góralski zgodził się z propozycją ks. R. Sztychmiler i uznał ją zbyt zasadną, podkreślił jednak, że mimo wszystko biskupi, szczególnie polscy, za rzadko wysyłają swoich kapłanów na studia w zakresie prawa kanonicznego.

Ks. Z. Janczewski podziękował Księdzu Przewodniczącemu za słowa uznania i podkreślił, że jego wykład był apelem do Konferencji Episkopatu Polski, stąd radość prelegenta była jeszcze większa ze względu na jego właściwe odczytanie, zrozumienie i pozytywny odbiór.

Przedmówcy wtórował ks. J. Krajczyński, który także podziękował za uznanie, niemniej zauważył, że poruszane propozycje są w kwestiach biskupów.

Ostatniej sesji łomżyńskiej konferencji przewodniczył ks. prof. dr hab. Leszek Adamowicz, Kierownik Katedry Prawa Katolickich Kościołów Wschodnich Katolickiego Uniwersytetu Lubelskiego. Przy stole prezydialnym miejsce zajęli prelegenci: ks. prof. dr hab. Mirosław Sitarz, Kierownik Katedry Kościelnego Prawa Publicznego i Konstytucyjnego KUL oraz dr Michał Zawiślak, także z KUL.

Referat ks. M. Sitarza dotyczył Zadania mediów w realizacji misji nauczycielskiej Kościoła w Polsce. Prelegent stwierdził, że w ostatnim czasie powstało kilka prac habilitacyjnych na temat mediów i Kościoła. Zaznaczył także, że Kodeks Prawa Kanonicznego nie normuje wykorzystywania Internetu jako medium, które może przysłużyć w realizacji zadania nauczania. Niewątpliwie Kościół nie może pozostać bierny w obliczu wyzwań ewangelizacyjnych w związku z mediami. Ks. M. Sitarz stwierdził, że media przyczyniają się do realizacji Ewangelii, do promocji godności osoby ludzkiej ze względu na to, że jest ona dziełem Boga, ukazywaniem obiektywnej Prawdy - Jezusa Chrystusa, który nieustannie poszukuje człowieka i pozwala mu się odnaleźć. Profesor M. Sitarz zakończył przywołaniem św. Maksymiliana Marii Kolbego, który nawoływał, że jeżeli Kościół zapomni o prasie, zatraci ewangelizację, straci współczesnego człowieka.

Ostatnie wystąpienie wygłosił dr Michał Zawiślak. Dotyczyło ono Podstaw realizacji misji nauczycielskiej Kościoła w prawie III Rzeczypospolitej. Prelegent wskazał fundament do realizacji zadań Kościoła w Rzeczypospolitej, ale i w każdym państwie. Jest nim prawo do wolności religijnej ze 
względu na godność osoby ludzkiej jako Stworzenia Bożego. Nauczanie religii w szkołach jest zagwarantowane w konkordacie, co niejako ułatwia działalnie Kościoła w pewnych ramach struktur państwowych. Dr M. Zawiślak w swoim wystąpieniu poruszył problem klauzuli sumienia, która jest dopuszczalna w sytuacjach krytycznych, a o której Kościół katolicki w Polsce jasno się wyraził. Ponadto prelegent zwrócił uwagę na fakt, że z autonomii państwa i Kościoła wynika autorytet biskupów w sprawach moralnych. Kończąc swoje wystąpienie dr M. Zawiślak wskazał na ogromne wyzwanie intelektualne głównie dla uniwersytetów jako naczelnych ośrodków myśli, które ma polegać na poszukiwaniu dialogu wiary i rozumu.

Ostatnią dyskusję podczas konferencji w Łomży rozpoczął ks. W. Górlaski, który zwrócił uwagę na próby dokonywania zmian w Funduszu Kościelnym, stwierdził, że takie zabiegi są niezgodne z art. 22 Konkordatu. Zaznaczył, że określenie państwo świeckie czy państwo wyznaniowe jest sformułowaniem niewłaściwym, ponieważ państwo w relacji do wiary i Kościoła jest neutralne.

W polemikę z twierdzeniami ks. W. Góralskiego wszedł ks. J. Krukowski, wybitny specjalista w zakresie prawa wyznaniowego i konkordatowego, który z niemałym zdenerwowaniem podkreślił konieczność właściwego stosowania norm wpisanych do Konstytucji, szczególnie w kontekście relacji Państwo-Kościół. Co więcej, Ksiądz Profesor skonstatował, że podczas prac nad polską ustawą zasadniczą, osobiście bronił umieszczenia w niej zapisów o laickości państwa polskiego. Stąd przyjęto model zaproponowany przez Sobór Watykański II, stanowiący o autonomii Państwa i Kościoła, ale także o ścisłej współpracy dla budowania lepszego porządku publicznego.

Swoją wypowiedz sprostował ks. W Góralski, który zaznaczył, że Polska nie jest państwem laickim, ale nie jest też państwem katolickim.

Do głosu wrócił ks. J. Krukowski, który uzupełnił swoją wypowiedź, stwierdzając, że model państwa polskiego jest zgodny z wezwaniem Pana Jezusa: Oddajcie cezarowi co cesarskie a Bogu to co należy do Boga. Stanowi to genezę stosunków Państwo-Kościół, szczególnie w Rzeczypospolitej.

Swoje pytanie do ks. M. Sitarza skierował ks. A. Domaszk: Czy spotkał się Ksiądz Profesor z trzecim wspótczesnym ekranem - Internetem? W odpowiedzi prelegent zaznaczył, że pojawia się coraz więcej rekolekcji za pośrednictwem Internetu, jest jednak duży problem z kontrolą przekazywanych $\mathrm{w}$ ten sposób treści religijnych. Internet służy także jednostkom kościelnym do organizowania spotkań, wyjazdów, zarówno przez młodzież, jak i jej duszpasterzy. Jeżeli chodzi o regulacje prawne ks. M. Sitarz wskazał 
jedynie synod łomżyński, który w swoich uchwałach zobowiązał kapłanów i wiernych do rozsądnej ewangelizacji przez to stosunkowo młode medium. Prelegent podsumował, że jak dotąd w swoich poszukiwaniach nie spotkał się z konkretnym programem duszpasterskim dotykającym zastosowania Internetu w ewangelizacji.

Uzupełnieniem tej wypowiedzi, były słowa ks. L. Adamowicza, który zaznaczył, że w Stanach Zjednoczonych powstają internetowe biuletyny parafialne według formularza zaakceptowanego i ujednoliconego przez diecezję.

Głos zabrał także ks. J. Krzywda. Zapytał, który ze środków masowych jest najpotężniejszy i od razu odpowiadając na tę kwestię stwierdził, że telewizja. Zastanawiał się także, jak Kościół jest obecny w telewizjach i jak poszerzyć możliwość większego udziału w mediach katolickiej doktryny.

Ks. M. Sitarz odpowiadając na pytanie wspaniale podsumował całość łomżyńskiej konferencji: Wiara rodzi się ze stuchania a nie oglądania.

Oficjalnego zamknięcia obrad dokonał Prezes Stowarzyszenia Kanonistów Polskich ks. prof. dr hab. Józef Krukowski oraz Jego Ekscelencja ks. bp dr Janusz Stepnowski, biskup diecezjalny łomżyński, który podziękował za obrady kanonistów i zaprosił ich ponownie, zawsze gdy będzie taka potrzeba. 